\title{
Potential food sources of Glycymeris nummaria (Mollusca: Bivalvia) during the annual cycle indicated by fatty acid analysis
}

\author{
Mirjana Najdek ${ }^{1}$, Daria Ezgeta-Balić ${ }^{2}$, Maria Blažina ${ }^{1}$, Marija Crnčević ${ }^{3}$, Melita Peharda ${ }^{2}$ \\ ${ }^{1}$ Institute "Ruđer Bošković", Centre for Marine Research, Giordano Paliaga 5, 52210 Rovinj, Croatia. \\ ${ }^{2}$ Institute of Oceanography and Fisheries, Setalište Ivana Meštrovića 63, 21000 Split, Croatia. E-mail: melita@ @izor.hr \\ ${ }^{3}$ Public Institution for the Management of Protected Natural Values in the Dubrovnik-Neretva County, Branitelja Du- \\ brovnika 41, 20000 Dubrovnik, Croatia.
}

\begin{abstract}
Summary: Seasonal changes of food sources were investigated by analysing the fatty acid profiles of digestive gland and muscle tissues of the naturally occurring clams Glycymeris nummaria in Mali Ston Bay, Croatia. Total lipids in the digestive gland and the adductor muscle showed parallel changes, with a maximum after the main spawning event in September. In the digestive gland saturated fatty acids were highly dominant (up to $82 \%$ ), indicating detritus as the main food source for this species. This type of food prevailed during the autumn/winter period, in contrast to the spring/summer period when detritus was enriched with phyto- and, to a lesser extent, zooplankton. Fatty acid composition of muscles indicated highly efficient utilization of ingested food through significant retention of polyunsaturated fatty acid from the clams' diet during the entire period investigated.
\end{abstract}

Keywords: feeding ecology; bivalve; Glycymerididae; Adriatic Sea; Mali Ston.

Fuentes potenciales de alimento en Glycymeris nummaria (Mollusca: Bivalvia) durante el ciclo anual a partir del análisis de ácidos graso

Resumen: Se han investigado los cambios estacionales en las fuentes de alimentación de poblaciones naturales del bivalvo Glycymeris nummaria en la bahía Mali Ston (Croacia) por medio del análisis de los perfiles de ácidos grasos de la glándula digestiva y del tejido muscular. El total de lípidos tanto de la glándula digestiva como en el músculo aductor mostró cambios similares después del principal evento de freza (septiembre). En la glándula digestiva los ácidos grasos saturados fueron altamente dominantes (hasta el 82\%), lo que señala a los detritos como principal fuente de alimentación de esta especie. Este tipo de alimento prevalece durante el otoño/invierno, mientras que en primavera/verano la alimentación se complementa con fitoplancton y, en menor medida, con zooplancton. La composición de ácidos grasos en el tejido muscular indica una alta eficiencia en la utilización del alimento ingerido mediante la retención de los ácidos grasos poliinsaturados (PUFA) de la dieta durante todo el periodo investigado.

Palabras clave: ecología trófica; bivalvo; Glycymerididae; Adriático; Bahía Mali Ston.

Citation/Como citar este artículo: Najdek M., Ezgeta-Balić D., Blažina M., Crnčević M., Peharda M. 2016. Potential food sources of Glycymeris nummaria (Mollusca: Bivalvia) during the annual cycleindicated by fatty acid analysis. Sci. Mar. 80(1): 123-129. doi: http://dx.doi.org/10.3989/scimar.04267.23A

Editor: J. Templado.

Received: May 7, 2015. Accepted: November 11, 2015. Published: January 20, 2016.

Copyright: (c) 2016 CSIC. This is an open-access article distributed under the Creative Commons Attribution-Non Commercial Lisence (by-nc) Spain 3.0.

\section{INTRODUCTION}

The clam Glycymeris nummaria (Linnaeus, 1758) (Bivalvia: Glycymerididae) is mainly a Mediterranean species, although it is also present in the Ibero-Moroccan Gulf of the Atlantic area (Gofas et al. 2011). In the Adriatic Sea this species is one of three glycymeridid species and lives buried in well-sorted sands at depths of 2-40 m (Legac and Hrs-Brenko 1999). Glycymeris nummaria is smaller than the other two glycymeridids, G. bimaculata (Poli, 1795) and G. pilosa (Linnaeus, 1767), attaining a shell length of less than $70 \mathrm{~mm}$ (Poppe and Goto 2000). Recent studies have described its distribution (Legac and Hrs-Brenko 1999, Rinaldi 
2002, Peharda et al. 2010), growth and longevity (Peharda et al. 2012a), and reproduction (Crnčević et al. 2013) in the Adriatic Sea.

Glycymeridid species are believed to be long-lived (Peharda et al. 2012a, Royer et al. 2013, Bušelić et al. 2015), so their shell is interesting for analysing growth increments and have been successfully used in the reconstruction of paleoenvironmental seawater temperature records (e.g. Schöne et al. 2011). In addition to temperature, food availability is the most important factor that regulates growth of marine invertebrates, including bivalves (MacDonald and Thompson 1986). Although there are some studies on the feeding ecology of other glycymeridids (Galap et al. 1999, Savina and Pouvreau 2004, Nerot et al. 2012), there are no data for G. nummaria. In recent years, bivalve feeding ecology has been widely investigated using methods including direct stomach content analysis (e.g. Lehane and Davenport 2002, 2004, Davenport et al. 2011, Peharda et al. 2012b), measurement of chlorophyll uptake using in situ fluorimeters (Comeau et al. 2010), estimation of stable isotope composition of bivalve tissues (e.g. Deudero et al. 2009, Allan et al. 2010, Perez et al. 2013), and fatty acid analysis (e.g. Allan et al. 2010, Najdek et al. 2013, Perez et al. 2013). Fatty acid analysis is widely used in studies of aquatic ecology to trace food sources (e.g. Dalsgaard et al. 2003, Shin et al. 2008). Fatty acids are considered effective biomarkers because certain groups of organisms (e.g. bacteria, diatoms and dinoflagellates) have characteristic suites of fatty acids that can be followed through food webs (e.g. Dalsgaard et al. 2003, Bergé and Barnathan 2005). Different tissues exhibit different fatty acid turnover rates. Hence, when trophic dynamics are investigated over long time periods, tissues with higher metabolic activities (e.g. digestive gland or gonad) give information about recent dietary items, while tissues with lower rates of fatty acid turnover (e.g. muscle or mantle) provide an "average" for food consumed over a longer period of time (Paulet et al. 2006). Furthermore, the fatty acid profile of tissues that are mainly constituted from polar lipids resulted from food consumed over a longer period of time and is mainly related to the physiological need of this tissue (e.g. muscle) to maintain cell membrane integrity (Delaporte et al. 2005, Pernet et al. 2007).

In this study we tested the hypothesis that analysis of fatty acids can reveal potential food sources of bivalve G. nummaria and their seasonal changes. To achieve this, we analysed two tissues with different fatty acid turnover rates: digestive gland and adductor muscle. These data, together with existing data on growth and reproduction of G. nummaria in Mali Ston Bay (Peharda et al. 2012a, Crnčević et al. 2013) and geochemical data on changes in shell composition are necessary for evaluating ecological drivers of growth rate in Glycymeris species.

\section{MATERIALS AND METHODS}

Sampling for this study was carried out in Mali Ston Bay, south Adriatic (42 $52^{\prime} 17^{\prime}$ N, $\left.17^{\circ} 39^{\prime} 08^{\prime \prime} \mathrm{E}\right)$ (Fig. 1) bi-monthly from January to November 2010. Every

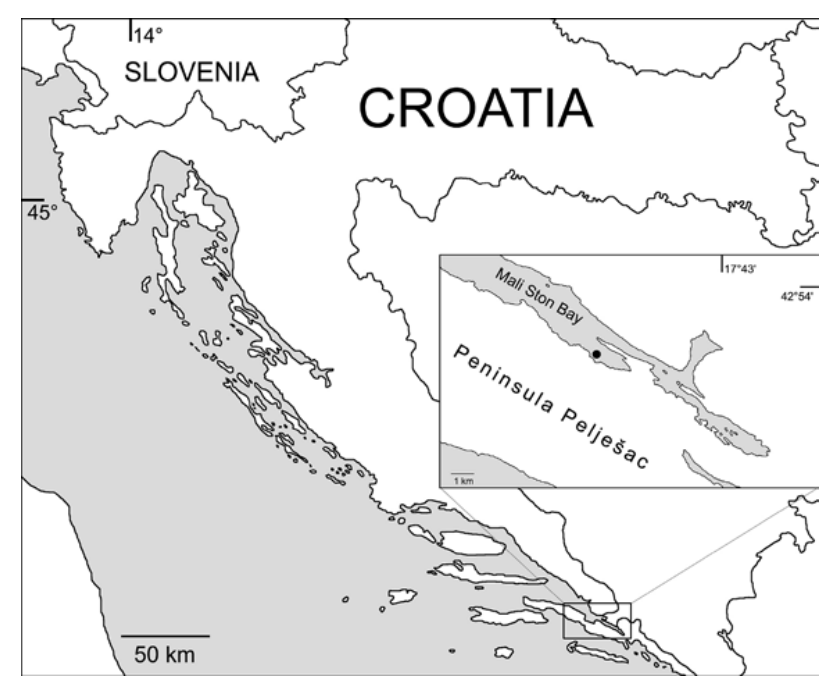

Fig. 1. - Map of the study area. The filled circle indicates the location of the sampling site.

two months, 12 specimens of Glycymeris nummaria were collected by commercial SCUBA at depths of 4-7 m. Mean length $( \pm \mathrm{SD})$ of specimens collected for fatty acid analysis was $60.6 \pm 3.7 \mathrm{~mm}$. Specimens were dissected shortly after collection to separate digestive gland and adductor muscle. Tissues from three animals were pooled randomly in four replicate samples for each organ. All samples were weighed, homogenized and extracted following Bligh and Dyer (1959) and total lipids were expressed as $\mathrm{mg} \mathrm{g}^{-1}$ (wet weight). Total extracts were saponified (1.2M NaOH in methanol), acidified $(6 \mathrm{M} \mathrm{HCl})$, methylated $(14 \% \mathrm{BF} 3$ in methanol) and extracted in dichloromethane (Morrison and Smith 1964). Fatty acid methyl esters (FAMEs) were analysed using an Agilent 6890N gas chromatography system equipped with a 5973 Network Mass Selective Detector, capillary column $(25 \mathrm{~m} \times 0.3 \mathrm{~mm} \times 0.25 \mu \mathrm{m}$, cross linked 5\% phenylmethyl siloxane) and ultra-high purity helium as the carrier gas. The gas liquid chromatography settings were programmed column temperature rise from $145^{\circ} \mathrm{C}$ by $4^{\circ} \mathrm{C} \mathrm{min}-1$ up to $270^{\circ} \mathrm{C}$ at a constant column pressure of $2.17 \mathrm{kPa}$. Retention times, peak areas and mass spectra were recorded with Chemstation software. FAMEs were identified by mass spectral data and a family plot of equivalent chain length data for GC standards for the GC column used. FAMEs mix C18-C20 and polyunsaturated fatty acid standards (PUFA1 and PUFA3, Supelco, Bellefonte, PA, USA), cod liver oil and various individual pure standards of FAMEs (Sigma, Steinheim, Germany) were used.

Differences between the organs in lipid content were tested by two sample t-tests (Systat 12). Differences in total lipids between months and organs and the interaction between factors were tested by two-way ANOVA (Systat 12). Normality and homogeneity of variances were tested by Lillefors and Levene tests, respectively. Significant ANOVA results $(\mathrm{p}<0.05)$ were followed by post hoc Tukey-HSD multiple comparison tests to determine which of the means were different. The results are presented as mean \pm sd.

A multivariate principal component analysis (PCA, Primer) was applied to identify food sources and po- 
tential fatty acid retention of $G$. nummaria during the study period according to fatty acid markers of bacteria, diatoms, dinoflagellates and microzooplankton. The analyses were based on correlation matrices involving the normalization of all variables due to their different scales.

\section{RESULTS}

Total lipid concentrations (TL, $\mathrm{mg} \mathrm{g}^{-1} \mathrm{ww}$ ) in the digestive glands of $G$. nummaria were significantly higher than in adductor muscle and varied significantly throughout the year (Fig. 2). Due to inconsistent variations of TL in two organs the interaction between the factors was significant (two-way ANOVA: factor organ, $\mathrm{F}=1350.199, \mathrm{p}<0.001$; factor month, $\mathrm{F}=5.455$, $\mathrm{p}=0.001$; organ*month $\mathrm{F}=4.707, \mathrm{p}=0.002)$. TL in digestive gland was similar in January $(36.4 \pm 6.3)$ and March (34.4 \pm 7.4 ), HSD, p $>0.05$, then abruptly increased in May (mean $\pm \mathrm{sd}=50.22 \pm 4.61$ ) and July (62.27 \pm 4.46$), \mathrm{HSD}, \mathrm{p}<0.05$. The highest values were recorded in September $(65.3 \pm 7.9)$ and then decreased in November $(31.9 \pm 5.2)$. In contrast, the year-round variations of total lipids in adductor muscles took place in narrow range $(4.3 \pm 1.2-5.4 \pm 1.5)$. In the colder months (January, March and November) the differences in TL between the organs were lower than in the warmer months (March, May and September).

The fatty acid composition of the digestive gland and adductor muscle of G. nummaria is shown in Table 1 and 2. In both organs, palmitic acid 16:0, palmitoleic 16:1 cis, oleic acid 18:1 (n-9) and eicosenoic acid 20:1 dominated among the saturated fatty acids (SATs) and monounsaturated fatty acids (MUFAs), respectively. Among the polyunsaturated fatty acids (PUFAs), highly unsaturated fatty acids (HUFA), arachidonic acid (ARA) 20:4(n-6), eicosapentaenoic (EPA) 20:5 (n-3)

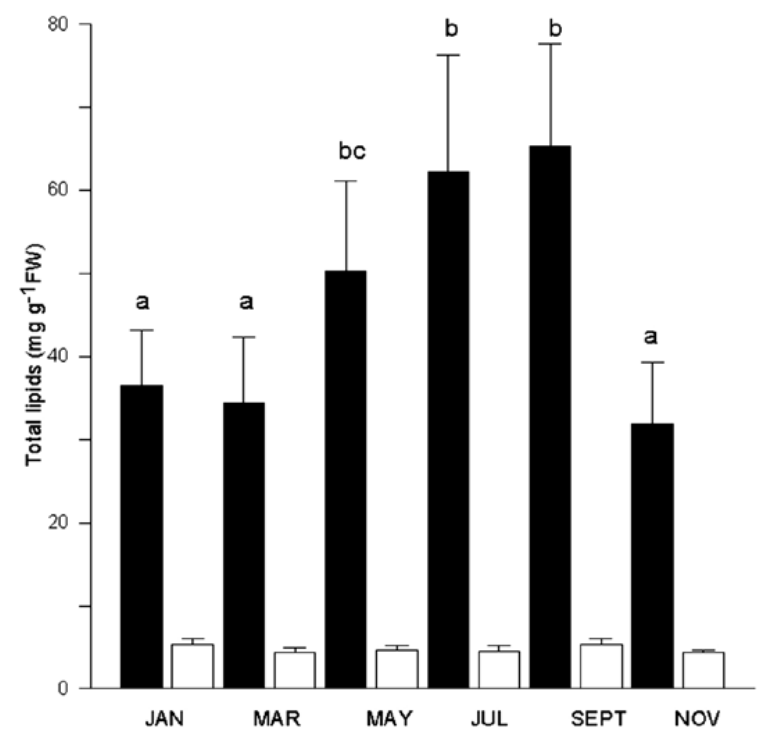

Fig. 2. - Seasonal variation of total lipids (mean \pm SD) in the digestive gland (black bars) and adductor muscle (white bars) in Glycymeris nummaria during year 2010. Different lowercase letters indicate significant differences between sampling months.

and docosahexaenoic (DHA) 22:6 (n-3) prevailed. The unsaturation degree (UND) was significantly higher in adductor muscle $(1.38-11.06,6.85 \pm 2.43)$ than in digestive glands $(0.25-2.49,1.09 \pm 0.71)$. UND was the highest in the digestive glands in May and in the adductor muscle in March. UNDs of both organs reached minimum values in September (two-way ANOVA: factor organ, $\mathrm{F}=2622.963, \mathrm{p}<0.001$; factor month, $\mathrm{F}=$ 123.271, $\mathrm{p}<0.001$; organ*month $\mathrm{F}=63.498$, $\mathrm{p}<0.001$ ).

Changes in HUFA in the digestive glands were similar throughout the study period, increasing from January to May and then decreasing to September

Table 1. - Fatty acid contribution (\%) in digestive gland of Glycymeris nummaria. FA, fatty acid; sd, standard deviation; NMID, nonmethylene-interrupted dienoic fatty acid; SAT, saturated fatty acid; MUFA, monounsaturated fatty acid; PUFA, polyunsaturated fatty acid; UND, unsaturation degree (Pirini et al. 2007); DHA, docosahexaenoic fatty acid; EPA, eicosapentaenoic fatty acid; ARA, arachidonic fatty acid; DETRITAL, detrital fatty acid [15:0+15iso+15anteiso+17:0+17iso+17anteiso+18:1(n-7)] (Mayzaud et al. 1989, Najdek et al. 2002).

\begin{tabular}{|c|c|c|c|c|c|c|}
\hline FA & $\begin{array}{c}\text { January } \\
\text { mean } \pm \text { sd }\end{array}$ & $\begin{array}{c}\text { March } \\
\text { mean } \pm \text { sd }\end{array}$ & $\begin{array}{c}\text { May } \\
\text { mean } \pm \text { sd }\end{array}$ & $\begin{array}{c}\text { July } \\
\text { mean } \pm \text { sd }\end{array}$ & $\begin{array}{c}\text { September } \\
\text { mean } \pm \text { sd }\end{array}$ & $\begin{array}{c}\text { November } \\
\text { mean } \pm \text { sd }\end{array}$ \\
\hline $14: 0$ & $6.65 \pm 0.36$ & $6.35 \pm 0.44$ & $10.07 \pm 0.64$ & $10.01 \pm 0.72$ & $9.87 \pm 1.09$ & $4.81 \pm 0.39$ \\
\hline $16: 0$ & $40.70 \pm 3.59$ & $36.13 \pm 2.53$ & $27.08 \pm 1.73$ & $31.00 \pm 2.23$ & $46.70 \pm 5.14$ & $55.90 \pm 4.58$ \\
\hline 18:0 & $12.15 \pm 2.82$ & $11.41 \pm 0.80$ & $7.32 \pm 0.47$ & $10.40 \pm 0.75$ & $14.77 \pm 1.62$ & $8.62 \pm 0.71$ \\
\hline $16: 1 \mathrm{cis}$ & $3.47 \pm 0.96$ & $4.11 \pm 0.29$ & $10.61 \pm 0.68$ & $8.38 \pm 0.60$ & $3.69 \pm 0.41$ & $4.02 \pm 0.33$ \\
\hline $18: 1(n-9)$ & $4.05 \pm 1.12$ & $6.65 \pm 0.47$ & $7.26 \pm 0.46$ & $8.79 \pm 0.63$ & $4.03 \pm 0.44$ & $4.51 \pm 0.37$ \\
\hline $18: 1(n-7)$ & $2.95 \pm 0.83$ & $0.39 \pm 0.03$ & $0.26 \pm 0.02$ & $0.36 \pm 0.03$ & $0.64 \pm 0.07$ & $1.95 \pm 0.64$ \\
\hline $20: 1$ & $2.39 \pm 0.62$ & $3.70 \pm 0.26$ & $3.50 \pm 0.22$ & $3.84 \pm 0.28$ & $2.29 \pm 0.25$ & $1.93 \pm 0.16$ \\
\hline $22: 1$ & $0.11 \pm 0.11$ & $0.26 \pm 0.02$ & $0.58 \pm 0.04$ & $0.44 \pm 0.03$ & $0.35 \pm 0.04$ & $1.14 \pm 0.09$ \\
\hline $18: 2(n-6)$ & $2.80 \pm 0.89$ & $3.09 \pm 0.22$ & $3.13 \pm 0.20$ & $3.25 \pm 0.23$ & $0.65 \pm 0.07$ & $2.53 \pm 0.21$ \\
\hline $18: 3(n-6)$ & $0.46 \pm 0.25$ & $1.04 \pm 0.07$ & $1.58 \pm 0.10$ & $0.74 \pm 0.05$ & $0.22 \pm 0.02$ & $0.88 \pm 0.07$ \\
\hline $18: 3(n-3)$ & $1.03 \pm 0.32$ & $1.81 \pm 0.13$ & $1.99 \pm 0.13$ & $1.68 \pm 0.12$ & $0.73 \pm 0.08$ & $1.06 \pm 0.09$ \\
\hline $20: 4(n-6)$ & $0.29 \pm 0.11$ & $0.89 \pm 0.06$ & $0.83 \pm 0.05$ & $0.59 \pm 0.04$ & $0.15 \pm 0.02$ & $0.44 \pm 0.04$ \\
\hline $20: 5(n-3)$ & $2.73 \pm 0.62$ & $3.31 \pm 0.23$ & $5.28 \pm 0.34$ & $2.87 \pm 0.21$ & $0.42 \pm 0.05$ & $0.94 \pm 0.08$ \\
\hline $22: 6(n-3)$ & $1.37 \pm 0.82$ & $4.33 \pm 0.30$ & $6.89 \pm 0.44$ & $3.16 \pm 0.23$ & $0.55 \pm 0.06$ & $0.78 \pm 0.06$ \\
\hline 22:2 NMID & $3.02 \pm 1.12$ & $3.17 \pm 0.22$ & $2.87 \pm 0.18$ & $3.11 \pm 0.22$ & $1.11 \pm 0.12$ & $2.13 \pm 0.17$ \\
\hline SAT & $70.26 \pm 3.30$ & $63.13 \pm 4.42$ & $49.39 \pm 3.16$ & $58.47 \pm 4.21$ & $81.98 \pm 9.02$ & $78.54 \pm 6.44$ \\
\hline MUFA & $12.20 \pm 1.81$ & $16.50 \pm 1.16$ & $23.14 \pm 1.48$ & $24.16 \pm 1.74$ & $11.28 \pm 1.24$ & $11.60 \pm 0.95$ \\
\hline PUFA & $14.20 \pm 2.29$ & $20.13 \pm 1.41$ & $25.68 \pm 1.64$ & $16.95 \pm 1.22$ & $3.93 \pm 0.43$ & $9.40 \pm 0.77$ \\
\hline UND & $0.37 \pm 0.12$ & $1.32 \pm 0.09$ & $2.49 \pm 0.16$ & $1.29 \pm 0.09$ & $0.25 \pm 0.03$ & $0.47 \pm 0.04$ \\
\hline $16: 1 / 16: 0$ & $0.09 \pm 0.02$ & $0.11 \pm 0.01$ & $0.39 \pm 0.03$ & $0.27 \pm 0.02$ & $0.08 \pm 0.01$ & $0.07 \pm 0.01$ \\
\hline DHA/EPA & $0.50 \pm 0.03$ & $1.31 \pm 0.09$ & $1.30 \pm 0.08$ & $1.10 \pm 0.08$ & $1.32 \pm 0.15$ & $0.83 \pm 0.07$ \\
\hline ARA/EPA & $0.11 \pm 0.01$ & $0.27 \pm 0.02$ & $0.16 \pm 0.01$ & $0.21 \pm 0.01$ & $0.35 \pm 0.04$ & $0.47 \pm 0.04$ \\
\hline DETRITAL & $8.79 \pm 2.36$ & $7.67 \pm 0.54$ & $4.22 \pm 0.27$ & $5.97 \pm 0.43$ & $8.83 \pm 0.97$ & $6.26 \pm 0.51$ \\
\hline
\end{tabular}


Table 2. - Fatty acid contribution (\%) in adductor muscle of Glycymeris nummaria. FA, fatty acid; sd, standard deviation; NMID, nonmethylene-interrupted dienoic fatty acid; SAT, saturated fatty acid; MUFA, monounsaturated fatty acid; PUFA, polyunsaturated fatty acid; UND, unsaturation degree (Pirini et al. 2007); DHA, docosahexaenoic fatty acid; EPA, eicosapentaenoic fatty acid; ARA, arachidonic fatty acid; DETRITAL, detrital fatty acid [15:0+15iso+15anteiso+17:0+17iso+17anteiso+18:1(n-7)] (Mayzaud et al. 1989, Najdek et al. 2002).

\begin{tabular}{|c|c|c|c|c|c|c|}
\hline FA & $\begin{array}{c}\text { January } \\
\text { mean } \pm \text { sd }\end{array}$ & $\begin{array}{c}\text { March } \\
\text { mean } \pm \text { sd }\end{array}$ & $\begin{array}{c}\text { May } \\
\text { mean } \pm \text { sd }\end{array}$ & $\begin{array}{c}\text { July } \\
\text { mean } \pm \text { sd }\end{array}$ & $\begin{array}{c}\text { September } \\
\text { mean } \pm \text { sd }\end{array}$ & $\begin{array}{c}\text { November } \\
\text { mean } \pm \text { sd }\end{array}$ \\
\hline $14: 0$ & $1.65 \pm 0.09$ & $2.08 \pm 0.14$ & $3.58 \pm 0.33$ & $2.36 \pm 0.22$ & $1.95 \pm 0.18$ & $2.57 \pm 0.13$ \\
\hline $16: 0$ & $23.72 \pm 2.06$ & $20.57 \pm 1.48$ & $20.61 \pm 1.92$ & $20.15 \pm 1.85$ & $27.81 \pm 2.59$ & $20.73 \pm 1.93$ \\
\hline $18: 0$ & $0.78 \pm 0.07$ & $1.44 \pm 0.07$ & $1.13 \pm 0.08$ & $1.82 \pm 0.13$ & $21.37 \pm 1.97$ & $2.40 \pm 0.23$ \\
\hline $16: 1$ cis & $5.43 \pm 0.47$ & $1.42 \pm 0.10$ & $3.47 \pm 0.23$ & $0.83 \pm 0.06$ & $2.19 \pm 0.20$ & $3.13 \pm 0.27$ \\
\hline $18: 1(n-9)$ & $3.45 \pm 0.30$ & $5.21 \pm 0.38$ & $6.35 \pm 0.43$ & $3.69 \pm 0.27$ & $4.54 \pm 0.42$ & $4.83 \pm 0.45$ \\
\hline $18: 1(\mathrm{n}-7)$ & $0.94 \pm 0.08$ & $1.00 \pm 0.07$ & $0.82 \pm 0.06$ & $0.63 \pm 0.08$ & $0.42 \pm 0.02$ & $0.56 \pm 0.03$ \\
\hline $20: 1$ & $3.15 \pm 0.27$ & $3.86 \pm 0.26$ & $5.28 \pm 0.49$ & $5.23 \pm 0.35$ & $5.76 \pm 0.41$ & $2.45 \pm 0.16$ \\
\hline $22: 1$ & $1.14 \pm 0.10$ & $0.52 \pm 0.03$ & $0.35 \pm 0.03$ & $1.19 \pm 0.08$ & $0.68 \pm 0.05$ & $2.39 \pm 0.17$ \\
\hline $18: 2(n-6)$ & $2.77 \pm 0.24$ & $3.87 \pm 0.26$ & $3.66 \pm 0.34$ & $3.72 \pm 0.25$ & $2.60 \pm 0.19$ & $3.08 \pm 0.28$ \\
\hline $18: 3(n-6)$ & $0.98 \pm 0.09$ & $1.30 \pm 0.09$ & $1.28 \pm 0.12$ & $1.89 \pm 0.10$ & $0.53 \pm 0.04$ & $1.23 \pm 0.11$ \\
\hline $18: 3(n-3)$ & $1.63 \pm 0.14$ & $1.75 \pm 0.12$ & $1.68 \pm 0.12$ & $1.65 \pm 0.15$ & $1.72 \pm 0.12$ & $1.38 \pm 0.13$ \\
\hline $20: 4(n-6)$ & $5.32 \pm 0.46$ & $5.72 \pm 0.42$ & $4.51 \pm 0.32$ & $5.17 \pm 0.48$ & $3.03 \pm 0.20$ & $4.74 \pm 0.44$ \\
\hline $20: 5(n-3)$ & $4.64 \pm 0.40$ & $7.74 \pm 0.56$ & $7.94 \pm 0.57$ & $5.14 \pm 0.47$ & $4.56 \pm 0.31$ & $5.26 \pm 0.38$ \\
\hline $22: 6(n-3)$ & $19.93 \pm 1.73$ & $20.27 \pm 1.48$ & $18.65 \pm 1.34$ & $20.98 \pm 1.93$ & $4.55 \pm 0.30$ & $19.22 \pm 1.79$ \\
\hline 22:2 NMID & $14.84 \pm 1.29$ & $12.04 \pm 0.88$ & $11.43 \pm 0.82$ & $13.55 \pm 1.25$ & $8.45 \pm 0.57$ & $12.46 \pm 1.16$ \\
\hline SAT & $29.59 \pm 2.57$ & $26.04 \pm 3.15$ & $27.72 \pm 4.20$ & $31.77 \pm 7.43$ & $57.69 \pm 7.85$ & $28.37 \pm 4.77$ \\
\hline MUFA & $16.17 \pm 1.33$ & $12.73 \pm 4.09$ & $17.57 \pm 1.85$ & $10.95 \pm 1.71$ & $13.18 \pm 1.29$ & $12.80 \pm 1.64$ \\
\hline PUFA & $53.34 \pm 4.64$ & $60.47 \pm 14.06$ & $54.18 \pm 8.66$ & $56.96 \pm 1.53$ & $28.80 \pm 3.06$ & $58.50 \pm 6.86$ \\
\hline UND & $7.30 \pm 0.64$ & $9.96 \pm 26.32$ & $7.25 \pm 0.52$ & $7.79 \pm 9.82$ & $1.38 \pm 0.15$ & $11.06 \pm 1.53$ \\
\hline $16: 1 / 16: 0$ & $0.23 \pm 0.02$ & $0.07 \pm 0.42$ & $0.17 \pm 0.54$ & $0.04 \pm 0.12$ & $0.08 \pm 0.01$ & $0.15 \pm 0.03$ \\
\hline DHA/EPA & $4.29 \pm 0.37$ & $2.62 \pm 0.86$ & $2.35 \pm 1.98$ & $4.08 \pm 1.03$ & $1.00 \pm 0.11$ & $3.65 \pm 0.61$ \\
\hline ARA/EPA & $1.14 \pm 0.10$ & $0.74 \pm 0.19$ & $0.57 \pm 0.52$ & $1.01 \pm 0.33$ & $0.66 \pm 0.07$ & $0.90 \pm 0.15$ \\
\hline DETRITAL & $4.38 \pm 0.29$ & $2.95 \pm 1.10$ & $2.39 \pm 0.65$ & $4.92 \pm 1.71$ & $4.75 \pm 0.51$ & $3.67 \pm 0.62$ \\
\hline
\end{tabular}

(Table 1). HUFA were retained in the muscle tissue throughout the year (Table 2). The lowest retention of HUFA occurred in September. Among HUFA the least retention was observed for EPA.

Non-methylene interrupted dienoic fatty acids (NMIDs) contributed appreciably to total PUFA in adductor muscles throughout the year. NMIDs varied oppositely to HUFA, but the significant correlation was only obtained with EPA (F-ratio $=7.880, \mathrm{p}<0.05$, $\mathrm{r}=-0.851$ ). In contrast, detrital FAMEs were always higher in the digestive glands than in muscles. The annual trend of detrital FAMEs in both organs was parallel and the correlation was significant $(\mathrm{F}=6.972$, $\mathrm{p}=0.018, \mathrm{r}=0.551)$. Detrital FAMEs in the digestive gland was oppositely correlated with diatom mark-

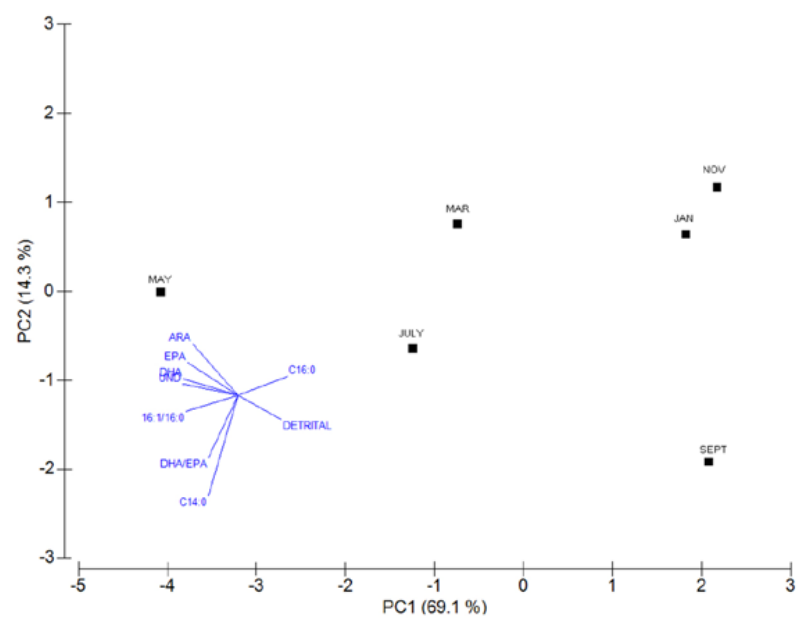

Fig. 3. - Principal component analysis plot of digestive gland (D) and adductor muscle (M) fatty acid proportions and ratios in Glycymeris nummaria sampled in 2010. PC1 and PC2: eigenvalues 6.40 and 1.52 , respectively. ers 16:1/16:0 ratios and EPA $(\mathrm{F}=16.097, \mathrm{p}<0.001$, $\mathrm{r}=-0.832, \mathrm{~F}=9.955, \mathrm{p}=0.006, \mathrm{r}=-0.619$, respectively).

Generally, DHA/EPA ratios in digestive glands were lower in the autumn-winter period $(0.5-0.8)$ and higher in spring-summer (1.1-1.3). In the adductor muscles DHA predominated over EPA throughout most of the year (2.4-4.3) or was present in a similar proportion to that of EPA in September (1.0). The ARA/EPA ratio in the digestive glands showed a generally increasing trend from January to November. In adductor muscles ARA/EPA decreased from January to May and then increased in July and remained more or less constant until November.

To elucidate the relative importance of different food sources and the efficiency of food utilization in G. nummaria during the year, PCA was applied to the fatty acid proportions (14:0, 16:0, ARA, EPA, DHA, detrital), ratios (DHA/EPA, 16:1/16:0) and the unsaturation index (UND) of the digestive glands and adductor muscles. PC1 and PC2 (eigenvalues 6.40 and 1.52 ) explained $71.7 \%$ and $16.9 \%$ of these variations, respectively (Fig. 3). For the separation of samples on positive PCs the equal influences of the proportion of 16:0 and detrital fatty acids (PC1) and 16:1/16:0 ratios (PC2) were observed. The separation of samples on negative PCs was equally influenced by the proportions of ARA, EPA, DHA, UND and DHA/EPA ratios (PC1) in addition to 16:0 and detrital fatty acids (PC2) (Fig. 3).

The digestive glands and adductor muscles of $G$. nummaria were clearly separated in relation to positive and negative $\mathrm{PC} 1$, respectively. Digestive glands in May and July were additionally separated from the rest of digestive glands on $\mathrm{PC} 2$ due to high values of 16:1/16:0 ratios in May and July. Similarly, the adductor muscles from May and July were separated from the rest of the muscles on PC2 due to high values of the 
16:1/16:0 ratio in May and detrital fatty acids in July. Adductor muscle in September differed from the other muscles resembling more to digestive glands (Fig. 3).

\section{DISCUSSION}

Total lipid concentrations in the adductor muscle of G. nummaria collected in this study were several times lower than in the digestive gland and although relatively stable during the entire study, an increase in January and September was observed. Similarly, in another glycymeridid species, G. glycymeris, increases in the lipid concentration of muscle were also recorded during the winter and/or during the period of vitellogenesis culminating in the autumn spawning period (Galap et al. 1997). Our study showed that the lipid content of the digestive gland of $G$. nummaria exhibited pronounced seasonal variation, as also reported for other species (Galap et al. 1999, Ezgeta-Balić et al. 2014). Digestive gland lipid concentrations of $G$. nummaria were similar to those observed for two bottom-dwelling bivalve species, Modiolus barbatus (Linnaeus, 1758) and Arca noae Linnaeus, 1758 from Mali Ston Bay, while species from aquaculture in the same bay, which live suspended in the water column (Mytilus galloprovincialis Lamarck, 1819 and Ostrea edulis Linnaeus, 1758), showed a generally lower lipid content in the digestive gland. Lipid content in the digestive gland in general followed the pattern of maturation of $G$. nummaria gonads (Crnčević et al. 2013) and increased from January to July. Maximal lipid concentration was recorded in September, when almost all analysed specimens, both males and females, were classified as spent. Galap et al. (1997) showed that variation in the lipid content of visceral mass was not clearly related to the state of gonad maturation, increasing and decreasing after spring and autumn spawning, respectively. As they analysed the entire visceral mass, it is impossible to obtain precise information about variation of the total lipids separately in the gonad, digestive gland and the rest of the viscera. Therefore, it seems very likely that $G$. nummaria continue to accumulate lipids and energy in the digestive gland after the spawning period to help maintain physiological integrity during winter, an adverse period for bivalves in terms of environmental conditions and food availability (Beninger and Lucas 1984).

Fatty acid analysis of the dog cockle, G. gylcymeris, from south Brittany, France showed that the highest concentrations were of saturated fatty acids, especially C20:0 in all analysed tissues (adductor muscle, foot, tunic coat, visceral mass and mantle), suggesting that bacteria associated with detrital matter contributed most to the food source (Galap et al. 1999). Although less abundant, PUFAs were also present in dog cockle tissues, indicating that phytoplankton was present in the diet (Galap et al. 1999). Similar results were obtained in the present study, where saturated fatty acids in G. nummaria digestive gland contributed up to $82 \%$ of total fatty acid content. Compared with data obtained from four commercially important species within Mali Ston Bay (O. edulis, M. galloprovincialis, M. barbatus and A. noae, Ezgeta-Balić et al. 2012), G. nummaria showed significantly higher levels of saturated fatty acid. This is probably because of a tighter association of G. nummaria with the detrital food chain because of its burrowing habit within soft sediments.

Our findings indicate that during September the diet of $G$. nummaria was predominantly made up of detritus. The low index of unsaturation of digestive glands' lipids at this time coincided with a known high incidence of poor condition indices, presumably reflecting the end of the intensive spawning period (Crnčević et al. 2013). We also found that detritus was the main food source in November and January, but the diet was of somewhat better quality. The increase of the HUFA proportion and the $\mathrm{C} 16: 1 / \mathrm{C} 16: 0$ ratios suggested the increase of phytoplankton and the accompanying decrease of the detrital component in the digested food. It seems that the digestive gland in this species does not act as an energy storage organ and that biochemical components assessed in it correspond to acquired food. The increase in food quality in terms of desaturation could be linked to maintenance of organism function under conditions of low temperature. It has been suggested that enhanced desaturation in response to decreased temperature could be masked by the influence of PUFAs of dietary origin (De Moreno et al. 1976). This idea is consistent with the observed rise in the index of unsaturation during the late autumn/ winter period (November and January), in comparison with September. From March to July, G. nummaria gonadal ripening occurred for both males and females (Crnčević et al. 2013). In this period the quality of digested food increased due to increased input of PUFAs, presumably derived from phytoplankton (inferred from the increase in proportion of EPA and the 16:1/16:0 ratio). In support of this, data collected during the same time period at a nearby location showed that the concentration of chlorophyll $a$ varied seasonally and was highest in April 2010 (Peharda et al. 2012b). Similarly, the highest abundance of microphytoplankton in Mali Ston Bay in 2002, occurred from March to June (Čalić et al. 2013). In addition, the presence of an animal component in the digestive gland of G. nummaria was indicated by DHA/EPA ratios favouring DHA over EPA. These two PUFAs, combined with ARA, could be transferred directly or via the detritus food chain to the microzooplankton and hence to the upper levels of the food chain (Ventrella et al. 2008). Their presence in digestive glands in such ratios most likely reflects a dietary contribution of mixed food sources, i.e. detritic matter enriched with phyto- and zooplankton.

The fatty acids of the adductor muscles were characterized by a higher level of highly unsaturated PUFAs (ARA, EPA, and DHA) and lower levels of MUFA and SAT than the digestive glands. The PUFAs are accumulated and play a structural role in maintaining membrane fluidity (especially at low temperature) for the acquisition of the energy required for diverse metabolic functions, and also as energy reserves during periods of nutritional shortage (Freites et al. 2002). In contrast to the digestive gland, the adductor muscle seems to act as storage tissue of energy reserves, exhib- 
iting quite a conservative strategy. Retention of ARA, EPA and DHA in the muscle tissue of G. nummaria was evident all year round. Their minimum values were recorded in September, after intense spawning, and coincided with poor condition indices in spent $G$. nummaria. These results are comparable with those of the other bottom-dwelling species from Mali Ston Bay (Ezgeta-Balić et al. 2012). Similarly, a decrease in the level of DHA and EPA was also recorded in neutral lipid fraction extracted from the whole tissue of Crassostrea virginica (Gmelin, 1791) after the spawning period (Trider and Castell 1980). ARA is a major precursor of eicosanoids, including prostaglandins, which simulate muscle contraction and egg release during spawning (Soudant et al. 1999, Palacios et al. 2005) as, according to Crnčević et al. (2013), occurred in $G$. nummaria from July to September. Besides retention of ARA, EPA and DHA, the adductor muscles of $G$. nummaria were also rich in NMIDs, found in comparable proportions to those for A. noae (Ezgeta-Balić et al. 2012, Dupčić-Radić et al. 2014). NMIDs and their precursor palmitoleic acid varied oppositely during the spring/summer period, implying that synthesis of NMIDs could also be stimulated by the presence of C16:1(n-7) derived from phytoplankton in the diet (Zhukova 1991). For G. nummaria, this pattern was not as clearly expressed as for the other bivalves in Mali Ston Bay (Ezgeta-Balić et al. 2012). However, in G. nummaria an increase of the NMIDs occurred when EPA decreased, in accordance with observations for Crassostrea corteziensis (Hertlein, 1951) (Hurtado et al. 2012) and supporting the idea that these fatty acids are synthesized during the shortage of the HUFAs, especially EPA. For $G$. nummaria the shortage of EPA was evident during the cold months (November, January) and after spawning (September). Since these two periods were very energetically demanding, by NMID synthesis G. nummaria manages to maintain PUFAs on a similar level. This finding is in line with the conservative strategy of this species, which stores the energy reserves to deal with diminishing food availability or poor condition.

\section{ACKNOWLEDGEMENTS}

The authors would like to thank Maro Franušić, Nela Sinjkević and Margita Radman for their technical assistance during field research and Prof. John Davenport for useful suggestions that improved the manuscript. The research was supported by the Croatian Ministry of Science, Education and Sport under grants numbers 098-0982705-2729 and 001-0013077-0532.

\section{REFERENCES}

Allan E.L., Ambrose S.T., Richoux N.B., et al. 2010. Determining spatial changes in the diet of nearshore suspension-feeders along the South African coastline: Stable isotope and fatty acid signatures. Est. Coast. Shelf Sci. 87: 463-471. http://dx.doi.org/10.1016/j.ecss.2010.02.004

Beninger P.G., Lucas A. 1984. Seasonal variations in condition, reproductive activity, and gross biochemical composition of two species of adult clam reared in a common habitat: Tapes decussatus L. (Jeffreys) and Tapes philippinarum (Adams and
Reeve). J. Exp. Mar. Biol. Ecol. 79: 19-37. http://dx.doi.org/10.1016/0022-0981(84)90028-5

Bergé J.P., Barnathan G. 2005. Fatty acids from lipids of marine organisms: molecular biodiversity, roles as biomarkers, biologically active compounds, and economical aspects. Adv. Biochem. Engin./Biotechnol. 96: 49-125.

Bligh E.G., Dyer W.J. 1959. A rapid method of total lipid extraction and purification. Can. J. Biochem. Phys. 37: 910-917.

Bušelić I., Peharda M., Reynolds D.J., et al. 2015. Glycymeris bimaculata (Poli, 1795) - a new sclerochronological archive for the Mediterranean? J. Sea Res. 95: 139-148. http://dx.doi.org/10.1016/j.seares. 2014.07.011

Comeau L.A., Sonier R., Lanteigne L., et al. 2010. A novel approach to measuring chlorophyll uptake by cultivated oysters. Aquac. Eng. 43: 71-77. http://dx.doi.org/10.1016/j.aquaeng.2010.06.002

Čalić M., Carić M., Kršinić F., et al. 2013. Controlling factors of phytoplankton seasonal succession in oligotrophic Mali Ston Bay (south-eastern Adriatic). Environ. Monit. Assess. 185: 7543-7563

Crnčević M., Peharda M., Ezgeta-Balić D., et al. 2013. Reproductive cycle of Glycymeris nummaria (Linnaeus, 1758) (Mollusca: Bivalvia) from Mali Ston Bay, Adriatic Sea, Croatia. Sci. Mar. 77: 293-300. http://dx.doi.org/10.3989/scimar.03722.10A

Dalsgaard J., John M.S., Kattner G., et al. 2003. Fatty acid trophic markers in the pelagic marine environment. Adv. Mar. Biol. 46: 229-352. http//dx.doi.oro/10.1016/S0065-2881(03)46005-7

Davenport J., Ezgeta-Balić D., Peharda M., et al. 2011. Size-differential feeding in Pinna nobilis L. (Mollusca: Bivalvia): exploitation of detritus, phytoplankton and zooplankton. Est. Coast. Shelf. Sci. 92: 246-254 http://dx.doi.org/10.1016/j.ecss.2010.12.033

Delaporte M., Soudant P., Moal J., et al. 2005. Incorporation and modification of dietary fatty acids in gill polar lipids by two bivalve species Crassostrea gigas and Ruditapes philippinarum. Comp. Biochem. Physiol. A. 140(4): 460-470. http.//dx doi.org/10.1016/j. . 140 2005.02.009

De Moreno J.E.A., Moreno V.J., Brenner R.R. 1976. Lipid metabolism of the yellowclam, Mesodesma mactroides: I. Composition of the lipids. Lipids 11: 334-340.

Deudero S., Cabanellas M., Blanco A., et al. 2009. Stable isotope fractionation in the digestive gland, muscle and gills tissues of the marine mussel Mytilus galloprovincialis. J. Exp. Mar. Biol. Ecol. 368: 181-188. http://dx.doi.org/10.1016/j.jembe.2008.10.008

Dupčić-Radić I., Carić M., Najdek M., et al. 2014. Biochemical and fatty acid composition of Arca noae (Bivalvia: Arcidae) from the Mali Ston Bay, Adriatic Sea. Med. Mar. Sci. 15(3): 520-531.

Ezgeta-Balić D., Najdek M., Peharda M., et al. 2012. Seasonal fatty acid profile analysis to trace origin of food sources of four commercially important bivalves. Aquaculture 334-337: 89-100. http://dx.doi.org/10.1016/j.aquaculture.2011.12.041

Ezgeta-Balić D., Lojen S., Dolenec T., et al. 2014. Seasonal differences of stable isotope composition and lipid content in four bivalve species from the Adriatic Sea. Mar. Biol. Res. 10(6): 625-634. http://dx.doi.org/10.1080/17451000.2013.833338

Freites L., Labarta U., Fernandez-Reiriz M.J. 2002. Evolution of fatty acid profiles of subtidal and rocky shore mussel seed (Mytilus galloprovincialis, Lmk.). Influence of environmental parameters. J. Exp. Mar. Biol. Ecol. 268: 185-204. http://dx.doi.org/10.1016/S0022-0981(01)00377-X

Galap C., Leboulenger F., Grillot J.-P. 1997. Seasonal variation in biochemical constituents during the reproductive cycle of the female dog cockle Glycymeris glycymeris. Mar. Biol. 129: 625-634.

Galap C., Netchitallo P., Leboulenger F., et al. 1999. Variations of fatty acid contents in selected tissues of the female dog cockle (Glycymeris glycymeris L., Mollusca, Bivalvia) during the annual cycle. Comp. Biochem. Physiol., A. 122: 241-254.

Gofas S., Moreno D., Salas C. 2011. Moluscos Marinos de Andalucía. Vol. 2. Servicio de Publicaciones, Universidad de Málaga, 343-798 pp.

Hurtado M.A., Racotta I.S., Arcos F., et al. 2012. Seasonal variations of biochemical, pigment, fatty acid, and sterol compositions in female Crassostrea corteziensis oysters in relation to the reproductive cycle. Comp. Biochem. Physiol. B. 163: 172-183. http://dx.doi.org/10.1016/j.cbpb.2012.05.011 
Legac M., Hrs-Brenko M. 1999. A review of bivalve species in the eastern Adriatic Sea. III. Pteriomorpha (Glycymerididae). Nat. Croat. 8: 9-25

Lehane C., Davenport J. 2002. Ingestion of mesozooplankton by three species of bivalve, Mytilus edulis, Cerastoderma edule and Aequipecten opercularis. J. Mar. Biol. Ass. U.K. 82: 615-619. http://dx.doi.org/10.1017/S0025315402005957

Lehane C., Davenport J. 2004. Ingestion of bivalve larvae by Mytilus edulis: experimental and field demonstration of larviphagy in farmed blue mussels. Mar. Biol. 145: 101-107. http://dx.doi.org/10.1007/s00227-003-1290-6

MacDonald B.A., Thompson R.J. 1986. Influence of temperature and food availability on the ecological energetic of the giant scallop Placopecten magellanicus III. Physiological ecology, the gametogenetic cycle and scope for growth. Mar. Biol. 93: 37-48. http://dx.doi.org/10.1007/BF00428653

Mayzaud P., Chanut J.P., Ackman R.G. 1989. Seasonal changes of the biochemical composition of marine particulate matter with special reference to fatty acids and sterols. Mar. Ecol. Prog. Ser. 56: 189-204.

Morrison W.R., Smith L.M. 1964. Preparation of fatty acid methylesters and dimethylacetals from lipids with boron fluoridemethanol. J. Lipid Res. 5: 600-608.

Najdek M., Degobbis D., Mioković D., et al. 2002. Fatty acid and phytoplankton composition of different types of mucilaginous aggregates in the northern Adriatic. J. Plankton Res. 24: 429-441. http://dx.doi.org/10.1093/plankt/24.5.429

Najdek M., Blažina M., Ezgeta-Balić D., et al. 2013. Diets of fan shells (Pinna nobilis) of different sizes: fatty acid profiling of digestive gland and adductor muscle. Mar. Biol. 160: 921-930. http://dx.doi.org/10.1007/s00227-012-2144-x

Nerot C., Lorrain A., Grall J., et al. 2012. Stable isotope variation in benthic filter feeders across a large depth gradient on the continental shelf. Est. Coast. Shelf. Sci. 96: 228-235. http://dx.doi.org/10.1016/j.ecss.2011.11.004

Palacios E., Racotta I.S., Kraffe E., et al. 2005. Lipid composition of the giant lion's pawscallop (Nodipecten subnodosus) in relation to gametogenesis I. Fatty acids. Aquaculture 250: 270-282. http://dx.doi.org/10.1016/j.aquaculture.2005.04.070

Paulet Y.-M., Lorrain A., Richard J., et al. 2006. Experimental shift in diet $\delta 13 \mathrm{C}$ : A potential tool for ecophysiological studies in marine bivalves. Org. Geochem. 37: 1359-1370. http://dx.doi.org/10.1016/j.orggeochem.2006.01.008

Peharda M., Ezgeta-Balić D., Vrgoč N., et al. 2010. Description of bivalve community structure in the Croatian part of the Adriatic Sea - hydraulic dredge survey. Acta Adriat. 51: 144-158.

Peharda M., Crnčević M., Bušelić I., et al. 2012a. Growth and longevity of Glycymeris nummaria (Linnaeus, 1758) from the eastern Adriatic, Croatia. J. Shellfish Res. 31: 947-950. http://dx.doi.org/10.2983/035.031.0406

Peharda M., Ezgeta-Balić D., Davenport J., et al. 2012b. Differential ingestion of zooplankton by four species of bivalves (Mollusca) in Mali Ston Bay, Croatia. Mar. Biol. 159(4): 881-895. http://dx.doi.org/10.1007/s00227-011-1866-5

Pernet F., Tremblay R., Comeau L., et al. 2007. Temperature ad- aptation in two bivalve species from different thermal habitat: energetic and remodeling of membrane lipids. J. Exp. Biol. 210: 2999-3014.

http://dx.doi.org/10.1242/jeb.006007

Perez V., Olivier F., Tremblay R., et al. 2013. Trophic resources of the bivalve, Venus verrucosa, in the Chausey archipelago (Normandy, France) determined by stable isotopes and fatty acids. Aquat. Living Resour. 26(03): 229-239. http://dx.doi.org/10.1051/alr/2013058

Pirini M., Manuzzi M.P, Pagliarani A., et al. 2007. Changes in fatty acid composition of Mytilus galloprovincialis (Lmk) fed on microalgal and wheat germ diets. Comp. Biochem. Physiol. B. 147: $616-626$ http://dx.doi.org/10.1016/j.cbpb.2007.04.003

Poppe G.T., Goto Y. 2000. European Seashells. Volume II. (Scaphopoda, Bivalvia, Cephalopoda). ConchBooks, Hackenheim, $221 \mathrm{pp}$.

Rinaldi E. 2002. Glycymeris (Glycymeris) insubrica (Brocchi, 1874) nelle acque antisanti la costa Romagnola (Mollusca, Bivalvia, Glycymerididae). Quad. Studi Nat. Romagna 16: 15-20.

Royer C., Thébault J., Chauvaud L., et al. 2013. Structural analysis and paleoenvironmental potential of dog cockle shells (Glycymeris glycymeris) in Brittany, northwest France. Palaeogeogr. Palaeoclimatol. Palaeoecol. 373: 123-132. http://dx.doi.org/10.1016/j.palaeo.2012.01.033

Savina M., Pouvreau S. 2004. A comparative ecophysiological study of two infaunal filter-feeding bivalves: Paphia rhomboides and Glycymeris glycymeris. Aquaculture 239: 289-306. http://dx.doi.org/10.1016/j.aquaculture.2004.05.029

Schöne B.R., Zhang Z., Radermacher P., et al. 2011. Sr/Ca and Mg/ $\mathrm{Ca}$ ratios of ontogenetically old, long-lived bivalve shells Arctica islandica) and their function as palaeotemperature proxies. Palaeogeogr. Palaeoclimatol. Palaeoecol. 302: 52-64. http://dx.doi.org/10.1016/j.palaeo.2010.03.016

Shin P.K.S., Yip K.M., Xu W.Z., et al. 2008. Fatty acids as markers to demonstrating trophic relationships among diatoms, rotifers and green-lipped mussels. J. Exp. Mar. Biol. Ecol. 357: 75-84. http://dx.doi.org/10.1016/j.jembe.2008.01.002

Soudant P., van Ryckeghem K., Marty Y., et al. 1999. Comparison of the lipid class and fatty acid composition between a reproductive cycle in nature and a standard hatchery conditioning of the Pacific oyster Crassostrea gigas. Comp. Biochem. Physiol. B. 123: 209-222. http://dx.doi.org/10.1016/S0305-0491(99)00063-2

Trider D.J., Castell J.D. 1980. Influence of neutral lipid on seasonal variation of total lipid in oysters, Crassostrea virginica. Proc. Natl. Shellfish Ass. 70: 112-118.

Ventrella V., Pirini M., Pagliarani A., et al. 2008. Effect of temporal and geographic factors on fatty acid composition of M. galloprovincialis from the Adriatic Sea. Comp. Biochem. Physiol. B. 149: 241-250. http://dx.doi.org/10.1016/j.cbpb.2007.09.012

Zhukova N.V. 1991. The pathway of the biosynthesis of nonmethylene-interrupted dienoic fatty acids inmollusks. Comp. Biochem. Physiol. B. 100: 801-804. http://dx.doi.org/10.1016/0305-0491(91)90293-M 